\title{
MODEL PEMBELAJARAN LITERASI DASAR DALAM MENGEMBANGKAN KEMAMPUAN KOGNITIF DAN BAHASA DI TAMAN KANAK-KANAK
}

\author{
Ervin Nurul Affrida \\ Fakultas Keguruan dan Ilmu Pendidikan, Universitas PGRI Adi Buana Surabaya \\ ervina@unipasby.ac.id
}

\begin{abstract}
Perkembangan kognitif dan bahasa di Taman Kanak-Kanak dapat dikembangkan melalui pembelajaran literasi. Adapun pembelajaran literasi pada anak berfokus pada menanamkan dasar-dasar literasi sebagai pondasi awal untuk mengembangkan kemampuan literasi anak di jenjang pendidikan selanjutnya. Penelitian ini menggunakan metode kualitatif dengan pendekatan deskriptif. Hasil penelitian menunjukkan bahwa pembelajaran literasi dasar di Taman KanakKanak menggunakan model bercerita dengan buku-buku bergambar, model puzzle huruf dan bergambar, serta model pembelajaran audiovisual dengan rekaman suara dan video. Model pembelajaran literasi dasar tersebut berfokus pada empat indikator yaitu aspek kemampuan menyimak, berbicara, menulis, dan membaca.
\end{abstract}

Kata Kunci: Literasi Dasar, Perkembangan Kognitif, Perkembangan Bahasa

\begin{abstract}
Cognitive and language development in Kindergarten can be developed through literacy learning. Children literacy learning focuses on basics of literacy as initial foundation for developing children's literacy skills at the next level of education. This study uses a qualitative method with descriptive approach. The results showed that basic literacy learning in kindergarten used storytelling models with picture books, letters and pictorial puzzle models, and audiovisual learning models with sound and video recordings. The basic literacy learning model focuses on four indicators, namely aspects of the ability to listen, speak, write, and read.
\end{abstract}

Keywords: Basic Literacy, Cognitive Development, Language Development

\section{PENDAHULUAN}

Pendidikan anak usia dini (PAUD) merupakan lembaga pendidikan yang menjadi pondasi awal dalam membentuk karakter dan kepribadian anak sebelum memasuki jenjang pendidikan selanjutnya. Menurut UU Sisdiknas Nomor 20 Tahun 2003 Pasal 1 Ayat 14 menyatakan bahwa PAUD merupakan suatu pembinaan dan pendidikan dengan pemberian rangsangan pada anak sejak lahir sampai usia 6 tahun dalam perkembangan jasmani, rohani sehingga anak siap memasuki tahap pendidikan selanjutnya (Permendiknas, 2009). Salah satu capaian perkembangan yang diperlukan anak sebagai upaya dalam mempersiapkan jenjang pendidikan selanjutnya adalah kemampuan dalam mengenal keaksaraan yang dikenal dengan perkembangan literasi.

Literasi didefinisikan sebagai kemampuan yang berkaitan dengan membaca, menulis, menyimak, dan berbicara (Whitehead, 2004). Pelaksanaan literasi pada anak usia dini di sekolah bertumpu pada peran guru sehingga diperlukan kualifikasi kompetensi guru yang mendukung sebagai fasilitator literasi.

Aktivitas-aktivitas literasi dari membaca, menulis, menghitung tersebut termasuk dalam tugas perkembangan anak ranah kognitif dan bahasa. Menurut teori perkembangan Piaget, anak usia prasekolah berada pada tahap perkembangan kognitif praoperasional 
yaitu belum bisa merepresentasikan obyek dengan penalaran abstrak. Sedangkan pada aspek perkembangan bahasa anak terdiri dari egocentric speech dan socialized speech. Egocentric speech terjadi ketika anak melakukan kontak dengan dirinya sendiri, sedangkan socialized speech terjadi ketika anak melakukan kontak dengan lingkungan sosialnya (Jahja, 2011). Oleh karena itu pembelajaran literasi dasar pada anak usia prasekolah bertujuan untuk menjadi pondasi awal perkembangan literasi anak untuk mempersiapkan jenjang pendidikan selanjutnya.

Perkembangan literasi pada individu dapat berkembang seumur hidup, tetapi dasar perkembangan literasi dimulai sejak usia dini (Wasik \& Carol, 2008). Oleh karena itu pembelajaran literasi dasar sangat penting untuk anak usia dini dalam mencapai tugas perkembangan kognitif dan bahasanya sehingga mempengaruhi perkembangan selanjutnya di masa mendatang. Pemerintah Indonesia menciptakan program khusus dalam mendukung literasi melalui Gerakan Literasi Sekolah (GLS) di setiap jenjang pendidikan.

Pengenalan literasi dasar salah satunya dapat dilaksanakan di Taman Kanak-Kanak (Graves, dkk, 2011). Adapun keberhasilan pembelajaran literasi dasar di Taman KanakKanak salah satunya bergantung pada model pembelajaran literasi dasar yang diterapkan. Oleh karena itu dalam penelitian ini berfokus untuk mengetahui model pembelajaran literasi dasar di Taman Kanak-Kanak. Kajian dalam penelitian ini dapat digunakan sebagai indikator ketercapaian aspek perkembangan kognitif dan bahasa anak usia prasekolah serta sebagai bahan evaluasi dalam meningkatkan program pembelajaran literasi dasar di Taman Kanak-Kanak.

\section{METODE PENELITIAN}

Untuk mengetahui model pembelajaran literasi dasar dalam mengembangkan kemampuan kognitif dan bahasa anak usia prasekolah di Taman Kanak-Kanak, metode penelitian yang digunakan adalah metode kualitatif dengan pendekatan deskriptif. Penelitian ini dilaksanakan di TK Kemala Bhayangkari 93. Metode penelitian ini dipilih karena dianggap sesuai untuk mengetahui deskripsi model pembelajaran literasi dasar yang di terapkan di TK.

Adapun teknik yang digunakan untuk mendapatkan partisipan penelitian menggunakan teknik purposive sampling yang dipilih dengan pertimbangan dan tujuan tertentu. Berdasarkan tujuan penelitian yang telah dirumuskan, maka partisipan penelitian adalah 3 guru sebagai fasilitator yang menerapkan literasi dasar di TK Kemala Bhayangkari 93. Teknik penggalian data yang digunakan dalam penelitian ini yaitu 1) wawancara, ditujukan kepada guru sebagai key informan yaitu guru; dan 2) observasi, berfokus pada kegiatan guru dalam mengimplementasikan pembelajaran literasi dasar di TK. Adapun teknik analisis dan pengorganisasian data menggunakan Model Miles dan Huberman dengan langkahlangkah sebagai berikut: 1) reduksi data, yaitu peneliti merangkum dan memfokuskan data yang diperoleh sesuai dengan tujuan penelitian; 2) menyajikan data dengan cara memberikan kode-kode untuk mempermudah analisis data; dan 3) kesimpulan, penarikan, dan verifikasi, yaitu data-data yang telah direduksi dan disajikan digunakan sebagai dasar penarikan kesimpulan yang didukung dengan bukti-bukti pada tahap pengumpulan data penelitian.

\section{HASIL DAN PEMBAHASAN}

Pendidikan anak usia dini (PAUD) sebagai lembaga pendidikan yang berperan dalam membentuk karakter dan kepribadian anak, serta membantu anak dalam mencapai tugas-tugas perkembangannya. Perkembangan kognitif dan bahasa merupakan aspek yang perlu dikembangkan pada masa usia prasekolah. Hal ini disebabkan, anak usia prasekolah mulai mengembangkan interaksi dengan lingkungan sosialnya sehingga perkembangan kognitif dan bahasa sebagai bekal penting untuk mencapai perkembangan sosialnya. 
Pembelajaran di Taman Kanak-Kanak (TK) yang mendukung perkembangan kognitif dan bahasa anak dikenal dengan istilah keaksaraan atau literasi. Berdasarkan penelitian yang dilakukan, pembelajaran literasi pada anak berfokus untuk memberikan dasar-dasar literasi sebagai pondasi awal dalam mengembangkan kemampuan literasi pada jenjang pendidikan selanjutnya. Model-model pembelajaran literasi dasar tersebut berorientasi pada empat indikator yaitu kemampuan menyimak, kemampuan berbicara, kemampuan menulis, dan kemampuan membaca. Dalam melatih kemampuan menyimak, guru menggunakan metode bercerita. Dalam pembelajaran ini diharapkan anak-anak tidak hanya mendengarkan cerita saja, melainkan mampu memahami isi cerita yang dibacakan oleh guru. Pemahaman terhadap isi cerita dimanfaatkan guru untuk merangsang kemampuan berbicara anak. Sehingga point pembelajaran tetap mengacu pada aspek literasi dasar anak yaitu melatih kemampuan berbicara anak. Selain itu, melalui kegiatan pembelajaran sentra dan pembelajaran di luar ruangan seperti jalan-jalan keliling lingkungan sekolah juga digunakan guru dalam melatih kemampuan berbicara anak. Kemudian mendengarkan cerita melalui rekaman suara maupun video bergambar juga digunakan untuk menstimulus kemampuan menyimak dan berbicara anak.

Kemampuan menulis dan membaca merupakan aspek literasi dasar yang menjadi salah satu indikator keberhasilan pembelajaran di TK untuk memasuki jenjang pendidikan selanjutnya. Guru melatih kemampuan tersebut salah satunya dengan menggunakan media buku-buku bergambar yang dilengkapi dengan latihan membaca dan menulis, serta puzzle huruf dan bergambar. Pembelajaran sehari-hari di TK Kemala Bhayangkari 93 mengandung konten pembelajaran literasi yang mencakup aspek kemampuan menyimak, kemampuan berbicara, kemampuan menulis, dan kemampuan membaca yang disesuaikan dengan tema dan subtema pembelajaran.

\section{KESIMPULAN}

Pembelajaran literasi dasar pada anak usia dini berorientasi pada pemberian dasardasar literasi sebagai pondasi awal anak dalam mengembangkan kemampuan literasi di jenjang pendidikan selanjutnya. Anak usia prasekolah di Taman Kanak-Kanak berada pada tahap perkembangan kognitif pra operasional yang belum bisa berpikir secara abstrak, sehingga pelaksanaan pembelajaran literasi dasar menggunakan model-model pembelajaran dengan menggunakan alat bantu atau media pembelajaran seperti model bercerita dengan media buku bergambar, puzzle huruf dan bergambar, serta rekaman suara dan video sebagai alat bantu audio visual dalam pembelajaran literasi dasar di Taman Kanak-Kanak.

\section{REFERENSI}

Astuti, T.P. (2012). Gambaran Perkembangan Literasi Emergen Anak Taman Kanak-Kanak dengan Alat Ukur Adaptasi Get Ready to Read. Universitas Diponegoro.

Graves, Mechael et.al. (2011). Teaching Reading in 21th Century: Motivating All Learners. Boston:P earson

Hapsari, W., Ruhaena, L., \& Prastiti. D.W. (2017). Peningkatan Kemampuan Literasi Awal Anak Prasekolah Melalui Program Stimulasi. Jurnal Psikologi. Vol. 4 No.44: 177-184.

Hurlock. E. (2004) Psikologi Perkembangan: Suatu Pendekatan Sepanjang Rentang Kehidupan (terjemahan). Jakarta: Erlangga.

Jahja, Y. (2011). Psikologi Perkembangan. Jakarta: Kencana.

Januarisdi. (2014). Literasi: Sebuah Tinjauan Kepustakaan. Universitas Negeri Padang.

irah, Oyah. A.S., Astuti. T. P., \& Siswati (2012). Membaca Bersama dan Perkembangan Literasi Anak Usia Dini. Jurnal Psikologi Indonesia. Jakarta: Himpunan Psikologi Indonesia: Vol.9 No.1. 
Morisson, S.G. (2016). Pendidikan Anak Usia Dini Saat Ini. Yogyakarta: Pustaka Pelajar.

Peraturan Pemerintah Nomor 137 Tahun 2014. Standar Nasional Pendidikan Anak Usia Dini. Jakarta: Departemen Pendidikan Nasional.

Rvachew, S. (2010). Language Development Literacy. University Canada: Collaboration Canadian Language Literacy and Research Network (CLLRNet).

Seefeldt, C \& Barbara A.Wasik. (2008). Pendidikan Anak Usia Dini Menyiapkan Anak Usia Tiga, Empat dan Lima Tahun Masuk Sekolah. Jakarta : PT Indeks.

Suhartono. (2005). Pengembangan Keterampilan Berbicara Anak Usia Dini. Jakarta: Depdiknas.

Suyono. (2009). Pembelajaran Efektif dan Produktif Berbasis Literasi: Analisis Konteks, Prinsip, dan Wujud Alternatif
Strategi Implementasinya di Sekolah. Jurnal Bahasa dan Seni. Tahun 37, Nomor, 2, Edisi Bulan Agustus.

UNESCO. (1992). Emergent Literacy in Early Childhood Education. The Mount Carmel International Training Center (MCTC): Course on Emergant Literacy in Early Chilldhood Education.

Undang-Undang Republik Indonesia Nomor 20 Tahun 2003. Sistem Pendidikan Nasional. Jakarta: Sekretariat Negara Republik Indonesia.

Yulina, W.A, Purbaningrum, E. (2018). Pengaruh Kegiatan Literasi terhadap Kemampuan Mengenal Keaksaraan Anak Usia 4-5 Tahun Kelompok A di TK Kusuma Kediri. Jurnal PAUD Teratai. Universitas Negeri Surabaya: Vol.7 No.1.

Whitehead, M. (2004). Children"s Early Literacy. London. Sage Publications Company. 